\title{
Nurse contribution to the construction of health policy in the state of Bahia (1925-1930)
}

\author{
Participação da enfermeira na construção da política de saúde na Bahia (1925-1930) \\ Participación de la enfermera en la construcción de la política de salud en Bahia (1925-1930)
}

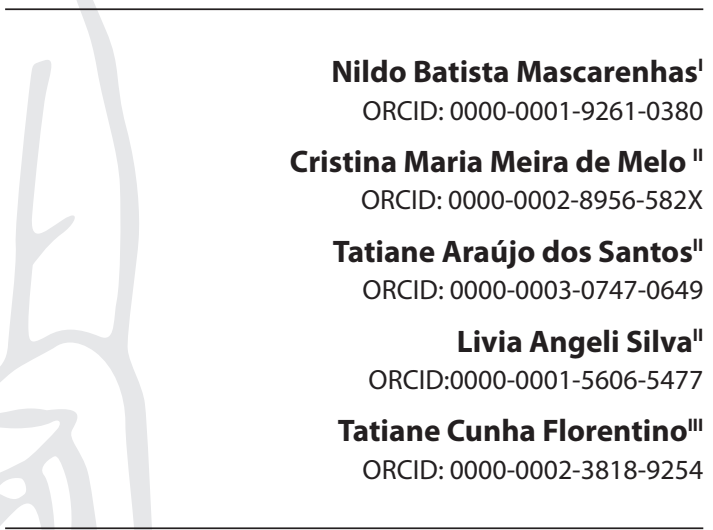

'Universidade do Estado da Bahia. Senhor do Bonfim, Bahia, Brazil.

"Universidade Federal da Bahia. Salvador, Bahia, Brazil.

"'Universidade Estadual de Feira de Santana. Feira de Santana, Bahia, Brazil.

How to cite this article: Mascarenhas NB, Melo CMM, Santos TA, Silva LA, Florentino TC. Nurse contribution to the construction of health policy in the state of Bahia (1925-1930). Rev Bras Enferm. 2021;74(1):e20200369. doi: http://dx.doi.org/10.1590/0034-7167-2020-0369

Corresponding author:

Nildo Batista Mascarenhas

E-mail: nildomascarenhas@gmail.com

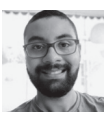

EDITOR IN CHIEF: Dulce Barbosa ASSOCIATE EDITOR: Antonio José de Almeida Filho

Submission: 06-29-2020

Approval: 10-21-2020

\begin{abstract}
Objectives: to analyze the contribution of nurses to the construction of health policy in the state of Bahia, from 1925 to 1930 . Methods: qualitative research, from a historical nature. Data were retrieved from five public archives, organized in a documentary corpus, and analyzed based on the health political analysis and the social control concepts, health policy and public health. Results: from 1925 to 1930, the State seized the work of the woman/nurse and established it in public health. This fact enabled the nurse's contribution to the construction of the health policy of the state of Bahia, which took place by the implementation of sanitary education actions, home visits and hygienic surveillance. Final Considerations: the female nurse's work made the health policy of the state of Bahia viable and was an ideal instrument to access homes and instruct/advise people in their daily lives to adopt behaviors that prevent the occurrence and, above all, the spread of diseases.

Descriptors: Work; Health Policy; Public Health; Nurse; History of Nursing.
\end{abstract}

\section{RESUMO}

Objetivos: analisar a participação da enfermeira na construção da política de saúde na Bahia entre 1925 e 1930. Métodos: pesquisa qualitativa de natureza histórica. Os dados foram coletados em cinco arquivos públicos, organizados em um corpus documental e analisados com base na análise política em saúde e nos conceitos de controle social, política de saúde e saúde pública. Resultados: entre 1925 e 1930, o Estado apropriou-se do trabalho da mulher/enfermeira e o institucionalizou no campo da saúde pública. Esse fato ensejou a participação da enfermeira na construção da política de saúde baiana, que ocorreu por meio da operacionalização das ações de educação sanitária, visita domiciliar e vigilância higiênica. Considerações Finais: o trabalho da enfermeira viabilizou a política de saúde baiana e foi um instrumento ideal para adentrar nos domicílios e ensinar/aconselhar as pessoas em seu cotidiano a adotarem condutas que evitassem a ocorrência e, sobretudo, a propagação das doenças.

Descritores: Trabalho; Políticas de Saúde; Saúde Pública; Enfermeira; História da Enfermagem.

\section{RESUMEN}

Objetivos: analizar la participación de la enfermera en la construcción de la política de salud en Bahia entre 1925 y 1930. Métodos: investigación cualitativa de carácter histórico. Los datos fueron recolectados en cinco archivos públicos, organizados en un corpus documental y analizados a partir del análisis político en salud y los conceptos de control social, política de salud y salud pública. Resultados: entre 1925 y 1930, el Estado se apropió del trabajo de la mujer/enfermera y lo institucionalizó en el campo de la salud pública. Este hecho dio lugar a la participación de la enfermera en la construcción de la política de salud en Bahia, que se dio a través de la operacionalización de acciones de educación en salud, visitas domiciliarias y vigilancia higiénica. Consideraciones Finales: el trabajo de la enfermera hizo viable la política de salud en Bahia y fue un instrumento ideal para ingresar a los hogares y enseñar/asesorar a las personas en su vida diaria a adoptar comportamientos para prevenir la ocurrencia de enfermedades y, sobre todo, su propagación.

Descriptores:Trabajo; Política de Salud; Salud Pública; Enfermeras; Historia de la Enfermería. 


\section{INTRODUCTION}

The 1920s can be considered a landmark for health policies in Brazil, given that, in this decade health was considered a public asset $^{(1)}$, or yet, it was transformed into a social issue ${ }^{(2)}$. Still in Hochman's conception, in such a decade, there were political opportunities that enabled the State to implement the first national health policies and carry out a broad sanitary reform ${ }^{(1)}$.

The objectives of the national health policy implemented in the 1920s were the sanitation of the interior of Brazil and social control. The focus was on the urban space enclosing and on private hygiene procedures, especially aimed at the popular classes, to prevent epidemics of infectious diseases that impaired commercial relations. To achieve these objectives, the national health policy developed strategies supported by the hygienist ideology and was put into operation through health and epidemiological surveillance actions, sanitary education, and home visits ${ }^{(1,3)}$.

As a strategy to guarantee the implementation of the national health policy, the State invested in qualifying the work of the woman/ nurse, allowing them to participate directly in the implementation of the state health policy ${ }^{(4)}$. The qualification of the female workforce and its subsequent insertion in institutionalized public health was a strategy to enable the implementation of health policy from the 1920s, given that the woman/nurse, when accessing homes and teaching the hygienist precepts via sanitary education actions, controlled and regulated the lives of men, women and children ${ }^{(4)}$.

The implementation of the national health policy of the 1920s had repercussions in the state of Bahia and triggered the institutionalization of the nurse's work from the year $1925^{(5)}$. Like what happened at the federal level, the State of Bahia invested in the nurse's work qualification so that this worker could practice health policy and to this end it was created a Serviço de Enfermeiras Sanitárias (Sanitary Female Nurses Service) and a Escola de Enfermeiras (School of Female Nurses) within the structure of the Subsecretaria de Saúde e Assistência Pública) (SSAP) (Sub Secretariat for Health and Public Assistance) $)^{(5)}$, which opened space for the nurse's contribution to the implementation of the state health policy.

In the Sanitary Code of the year 1925, the first in the state of Bahia ${ }^{(6)}$, the Sanitary Female Nurses Service (Serviço de Enfermeiras Sanitárias) was conceived as a division responsible for the control and qualification of nurses ${ }^{\prime}$ work in the public health area ${ }^{(7)}$. The Female Nurses School was established to train professional nurses who would work exclusively in the services under the responsibility of SSAP(7). The curriculum of this School and the criteria for choosing female students were similar to the Escola de Enfermeiras do Departamento Nacional de Saúde Pública (EEDNSP) (School of Feminine Nurses of the National Department of Public Health) ${ }^{(7)}$, currently Escola de Enfermagem Anna Nery (Anna Nery School of Nursing) at the Universidade Federal do Rio de Janeiro, which at that historic moment was considered a national reference for the female professional nurses training (modern nurse) and whose curricular and administrative bases were inserted in the Health Code of the year 1923 of the Departamento Nacional de Saúde Pública (DNSP) (Public Health National Department) ${ }^{(4)}$.

The inclusion of the Sanitary Female Nurses Service and the Female Nurses School in the structure of the SSAP, and in the text of the Sanitary Code of the year 1925, suggests the implementation in the state of Bahia of a professional nursing project similar to the one implemented in Rio de Janeiro, from the year 1922, by the North American nurse Ethel Parsons ${ }^{(8)}$. In this professional nursing project, which served the interests of fractions of the Brazilian medical elite, it was suggested the creation of a Female Nurses Service and a Female Nurses School at the DNSP, which took place in the years 1922 and 1923 respectively ${ }^{(4)}$.

The creation of the Female Nursing Service and Female School of the Escola de Enfermeiras da Subsecretaria de Saúde e Assistência Pública) (EESSAP) (Sub secretariat for Health and Public Assistance) highlights the strategic value of the work of qualified women/ nurses for the development of public actions in the public health area, mostly for the implementation of health policy in the years $1920 \mathrm{~s}^{(8)}$. Within the SSAP scope, no other professional department in the health area, except the area of nursing, had a centralizing body for its activities, even though in the year of 1925 the public teaching and control of professional practice in the areas of dentistry, pharmacy and medicine was already institutionalized ${ }^{(5)}$.

It is worth mentioning that the nurses' contribution in the construction of state health policy in the years of 1920s took place in the context of the genesis of professional female nursing work at the federal level ${ }^{(4)}$ and, for this, the State seized the female labor force, qualified for the activities of District Female Nurse and Sanitary Female Nurse (in the case of the state of Bahia), inserted her in institutions and/or health departments under its responsibility and organized the use of this workforce in the public health area ${ }^{(8)}$.

That said, it was defined as a research question: how did the female nurse contribute to the construction of health policy in the state of Bahia, from 1925 to 1930 ?

\section{OBJECTIVES}

To analyze the contribution of female nurses in the construction of health policy in the state of Bahia, from 1925 to1930.

\section{METHODS}

\section{Ethical aspects}

According to the rules and guidelines established in Resolution 466/2012, of the National Health Council (CNS), this research was not submitted to an Ethics in Research Committee (CEP), as it uses only public and freely accessible documents.

\section{Study design}

It is a qualitative research, from historical nature. The chronological mark begins on August $2^{\text {nd }}$ of the year 1925 and ends on November $5^{\text {th }}$ of the year 1930 . The first celebrates the publication of Law n. 1811, which created the Sub Secretariat for Health and Public Assistance, and the first attempt to implement modern nursing in the state, while the second corresponds to the publication of Regulation n'. 7068, which besides reestablishing the Diretoria Geral de Saúde Pública (General Directorate of Public Health) and extinguishing the SSAP, determined the decline of the sanitary reform project developed in the years of 1920s and the decline of the public health nurse implemented in that period. Finally, 
the study was guided by the Consolidated Criteria for Reporting Qualitative Research (COREQ) protocol.

\section{Theoretical-methodological framework}

The concepts of social control were used, understood as a set of mechanisms used by the instituted social order to discipline society, influence behavior, keep a certain order and put individuals to certain social standards and moral principles ${ }^{(9)}$; of health policy, assumed as a historical product of the established relations between society and the State, resulting from state decisions or non-decisions, which, when intervening on human needs and/or their socio-environmental determinants, produces economic, political and ideological effects ${ }^{(10)}$; and public health, considered as a government policy and expression of a techno-assistance model, this last one expressing a policy project organically articulated to certain social forces, which work in the political decision arenas, and is associated with historical alternatives and the relationship between the State and social classes $^{(11)}$. Moreover, the concept of political analysis in health with a focus on the political process was also used, which considers power relations within and outside institutions from the facts production and their relationship with health ${ }^{(12)}$.

\section{Setting}

The research took place in the state of Bahia, which during the study period reached a conservative modernization of the public health area, mainly featured by progress in health legislation and by institutional and administrative instruments ${ }^{(3)}$. This progress was possible because in the years 1920s, the Northeast became the main target of federal action and the state of Bahia, in particular, was directly affected by the national health policy ${ }^{(3)}$.

It should also be highlighted that in the years of 1920s, the modernization of public health of the state of Bahia was strongly associated with the ideologies of creation of the Brazilian nation-State and resulted from pressure from the federal government, which through DNSP induced a sanitary reform in the state and assumed responsibility (technical and financial) in the implementation of actions aimed at confronting endemic and epidemic diseases at the state level ${ }^{(3)}$, even in a fragmented political-economic situation and in territories dominated by regional and traditional oligarchies ${ }^{(8)}$.

\section{Data collection and organization}

Data collection was carried out at the Public Archive of the State of Bahia, at the Public Library of the State of Bahia, at the library of the Escola Estadual de Saúde Pública Professor Francisco Peixoto Magalhães Netto (EESP) (State School of Public Health Professor Francisco Peixoto Magalhães Netto) current Escola de Saúde Pública da Bahia (School of Public Health of the state of Bahia), at the University Library Professor Álvaro Rubim de Pinho, from the Universidade Federal da Bahia (UFBA), and at the Centro de Documentação da Escola de Enfermagem Anna Nery (Documentation Center of the Anna Nery School of Nursing), Universidade Federal do Rio de Janeiro. Besides the research on the aforementioned collections, an unsystematic search was also carried out on virtual research platforms, such as Google
Scholar (https://scholar.google.com.br/) and the Virtual Health Library (brasil.bvs.br), and also on the Revista Baiana de Saúde Pública (Bahia Journal of Public Health) website (http://rbsp. sesab.ba.gov.br/index.php/rbsp) and in the Revista Baiana de Enfermagem (Journal of Nursing of the state of Bahia) (https:// portalseer.ufba.br/index.php/enfermagem).

During this stage, a documentary corpus was built, whose purpose was to organize and group historical evidence ${ }^{(13)}$. This corpus was composed of different types of historical sources. Also, a field diary was used to record reflections and questions that came up during the investigation of the research object. The content of the diary was incorporated into the analysis of historical evidence and allowed to retrieve interpretations of the documents that helped to build the final synthesis ${ }^{(8)}$.

\section{Data source}

Different types of historical sources were combined into the study, namely: official documents (laws, decrees, management reports, internal communications, regulations and other information of interest inserted in the Official State Newsletter [Diário Oficial do Estado]); written speeches by agents involved in the formulation and implementation of health policy; academic works related to the object of study (books, book chapters, scientific articles, doctorate theses, master's degree dissertations and graduation course final papers) ${ }^{(8)}$.

\section{Data analysis}

The set of documentary sources was analyzed based on four concepts $^{(9-12)}$ and also considering the micro and macrostructural relationship among the State, health policy and the nurse's work. In the analysis process, it was also considered the content of the female nurse's work and the training of female nurses in public health.

\section{RESULTS}

Following the federal experience, in the years 1920s the state of Bahia inserted the female nurse as the health apparatus of the State and created departments responsible for qualifying and controlling this workforce in the area of public health, i.e., the Sanitary Female Nurses Service and EESSAP ${ }^{(14)}$. The Sanitary Female Nurses Service was a subsection of the Directoria de Epidemiologia e Prophylaxia Geral (Directorate of Epidemiology and General Prophylaxia) and a pioneer structure in the state of Bahia ${ }^{(14)}$. Hierarchically, the Service was located at the same level as the other subsections, showing its importance and the emerging profession (modern female nurse) for the implementation of the health policy of the years $1920 \mathrm{~s}^{(8)}$.

The main roles of the Sanitary Female Nurses Service were to centralize the command of nursing actions in the area of public health, assist the sanitary authority and carry out hygienic surveillance, control and prevention of infectious diseases and sanitary education actions in homes and schools ${ }^{(7,15)}$. Furthermore, this subsection was the link between health services and the homes where people lived, allowing SSAP to measure the scope of their actions and monitor compliance with medical and sanitary directives ${ }^{(8)}$.

The management of the Sanitary Female Nurses Service was carried out by a qualified female worker, unlike the other female 
nursing workers, a chief female nurse qualified by the EEDNSP and appointed by the Subsecretário de Saúde e Assistência Pública (Subsecretary of Health and Public Assistance). Further to this chief female nurse, the Sanitary Female Nurses Service, at the time of its creation, was composed of five district female nurses, fifteen female sanitary nurses and a typewriter. All female nurses, except for the chief female nurse, should be hired by public exam ${ }^{(7,16)}$.

Regarding the position of the female nurse in the area of public health, it was found that this worker was a career employee (Chart 1), hierarchically lower to the man/doctor and whose salary was lower when compared to the male careers that required qualification diploma (doctors, pharmacists, dentists and engineers) and other positions held by men in the SSAP structure (storekeeper, administrator, clerk, cartographer, chief doorman) (Figure 1) ${ }^{(8)}$.When comparing the salaries of commissioned and management positions, it was identified that the position of Chief female nurse had the lowest salary, although with duties and functions equivalent to those of the other directors and heads of services ${ }^{(7,15)}$, which reveals the sexual division of labor within the $\operatorname{SSAP}^{(8)}$.

Chart 1 - Mode of provision and requirements for the admission of female nurses to the Sanitary Female Nurses Service, Salvador, Bahia, Brazil, 2020

\begin{tabular}{|c|c|c|}
\hline Role & Provision & Requirements \\
\hline $\begin{array}{l}\text { Chief female } \\
\text { nurse }\end{array}$ & $\begin{array}{l}\text { Commissioned position, } \\
\text { occupied after the appointment } \\
\text { of the sub secretariat of health } \\
\text { and public assistance and } \\
\text { designated by the governor. }\end{array}$ & $\begin{array}{l}\text { Public health } \\
\text { female nurse } \\
\text { certified by } \\
\text { the EEDNSP or } \\
\text { other similar } \\
\text { establishments. }\end{array}$ \\
\hline $\begin{array}{l}\text { District } \\
\text { female nurse }\end{array}$ & $\begin{array}{l}\text { Public exam or designated by } \\
\text { the sub secretariat of health } \\
\text { and public assistance in case } \\
\text { the candidate had a specialized } \\
\text { certification in official } \\
\text { establishments or an internship } \\
\text { certificate at the Oswaldo Cruz } \\
\text { Institute of Rio de Janeiro, } \\
\text { Butantã Institute, or similar } \\
\text { establishments. }\end{array}$ & $\begin{array}{l}\text { EESSAP female } \\
\text { nurses course. }\end{array}$ \\
\hline $\begin{array}{l}\text { Sanitary } \\
\text { female nurse }\end{array}$ & $\begin{array}{l}\text { Public exam or designated by } \\
\text { the sub secretariat of health } \\
\text { and public assistance in case } \\
\text { the candidate had a specialized } \\
\text { certification in official } \\
\text { establishments or an internship } \\
\text { certificate at the Oswaldo Cruz } \\
\text { Institute of Rio de Janeiro, } \\
\text { Butantã Institute, or similar } \\
\text { establishments. }\end{array}$ & $\begin{array}{l}\text { EESSAP female } \\
\text { nurses course. }\end{array}$ \\
\hline
\end{tabular}

Note: EEDNSP - Escola de Enfermeiras do Departamento Nacional de Saúde Pública (School of Feminine Nurses of the National Department of Public Health); EESSAP - Escola de Enfermeiras da Subsecretaria de Saúde e Assistência Pública (Female School of Sub secretariat for Health and Public Assistance).

Source: Código Sanitário Estadual (State Health Code) ${ }^{(7)}$; Mascarenhas $(2018)^{(8)}$.

Concerning the duties of each type of female nurse (Chart 2 ), it was observed that in the structure of the SSAP these were distinguished from the position they held: as Chief female nurse, this worker would take care of the sanitary administration and had a hierarchical position higher to the other nurses; as a District female nurse, in which the work was directed to the supervision and inspection of the sanitary nurses' work, occupying an intermediate position in the hierarchy of the Sanitary Female Nurses
Service; in the position of Sanitary nurse, the work was assisting, characterized as manual (sanitary assistance) and hierarchically dependent to the immediate superior (district female nurse) ${ }^{(8)}$.

\section{$51-$}

\section{TABELLA DE VENCIMENTOS}

\section{Cargos} PESSOAL TITULADO

Sub-Secretario de Saúde e Assistencia

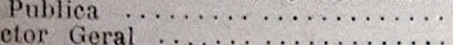

Director, Chefe de Serviço, Delegado de

Saúde da Capital ...............

Sub-Director, inspector sanitario, medico assistente, inspector vaceinador, encenheiro sanitario da Assiscia Publica, verificador de obito,

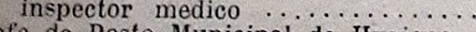

Chefe de Posto Municipal de Hygiene...

Medico auxiliar, engenheiro auxiliar chefe do posto de saneamento rural

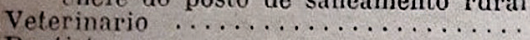

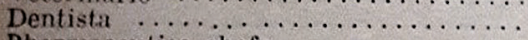

Pharmaceutico-chefe

Pharmaceutico

Enfermeira-co auxiliar $\ldots \ldots \ldots \ldots \ldots$

Enfermeira districtal, auxiliar iechnico

Enfermeira sanitaria $\ldots \ldots \ldots \ldots \ldots \ldots \ldots$

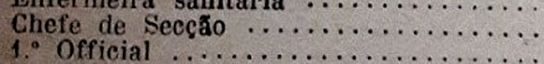

2. Official $\ldots \ldots \ldots \ldots \ldots \ldots \ldots \ldots \ldots \ldots \ldots \ldots$

Amanuense Official $^{2} \ldots \ldots \ldots \ldots \ldots \ldots \ldots \ldots \ldots \ldots \ldots \ldots \ldots$

Amanuense Almoxarife $_{\text {Geral }} \ldots \ldots \ldots \ldots \ldots \ldots \ldots \ldots \ldots$

Almoxarife $\quad \ldots \ldots \ldots \ldots \ldots \ldots \ldots \ldots \ldots$

Administrador $\ldots \ldots \ldots \ldots \ldots \ldots \ldots \ldots \ldots \ldots$

Cartographo $\ldots \ldots \ldots \ldots \ldots \ldots \ldots \ldots \ldots \ldots$
Porteiro-chote $\ldots \ldots \ldots \ldots \ldots \ldots \ldots$
Porteiro $\ldots \ldots \ldots \ldots \ldots \ldots \ldots$

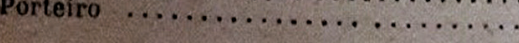

ncimentos annuaes

$18: 000 \$ 000$ 12:000\$000

$9: 992 \$ 000$

$9: 192 \$ 000$

$8: 400 \$ 000$

$6: 000 \$ 000$

$6: 9288000$

$7: 200 \$ 000$

7:488\$000

$5: 856 \$ 000$

4:200\$000

4:800\$000

$3: 600 \$ 000$

3:000\$000

$8: 280 \$ 000$

$7: 488 \$ 000$

$5: 856 \$ 000$

4:956\$000

4:056\$000

7:200\$000

$6: 588 \$ 000$

5:856\$000

4:800\$000

4:056\$000

$3: 240 \$ 000$

Source: Código Sanitário Estadual (State Health Code) $)^{(7)}$.

Subtitles:

SALARYTABLE

Position

Annual Salary

TITLEDSTAFF

Subsecretary of Health and Public Assistance

Managing Director

Director, Head of Service, Capital Health Delegate

Sub Director, sanitary inspector, assistant physician, vaccinating inspector,

Public Assistance sanitary engineer, obituary surveyor, medical inspector $\quad 9: 192 \$ 000$ Head of Municipal Hygiene Station

Assistant physician, auxiliary engineer chief of the rural sanitation station

Vet

Dentist

Chiefpharmacist

Pharmacist

Auxiliary pharmacist

Head nurse

District nurse, technical assistant

Sanitary nurse

Head of Department

$1^{\text {st }}$ Official

$2^{\text {nd }}$ Official

$3^{\text {rd }}$ Official

Clerk

General Storekeeper

Figure 1 - Salary table for trained Sub Secretariat for Health and Public As sistance (Subsecretaria de Saúde e Assistência Pública) personnel, Salvador, Bahia, Brazil, 2020

Concerning EESSAP, the objectives were to educate and qualify general or specialized professional female nurses. EESSAP was under the responsibility of the Sanitary Female Nurses Service and was 
managed by the Chief Female Nurse. The requirements to access this school were to be a woman; aged from 21 to 35 years old; certified by a Normal School, by the Ginásio da Bahia (High School of the state of Bahia) or by another similar institution; prove the absence of infectious diseases and/or physical condition; show a certificate of good conduct, issued by two righteous people and with the approval of the Board; present a receipt of an enrollment fee stipulated in the State Sanitary Code ${ }^{(7-8,15)}$. Also, it was established that students who behave inappropriately to morality or decency or contracted tuberculosis, cancer or leprosy would be eliminated from the course ${ }^{(7-8,15)}$.

Chart 2 - Duties of female nurses in the Sanitary Female Nurses Service, Salvador, Bahia, Brazil, 2020

\begin{tabular}{|c|c|}
\hline Role & Duties \\
\hline $\begin{array}{l}\text { Chief } \\
\text { female } \\
\text { nurse }\end{array}$ & $\begin{array}{l}\text { - Management of the Sanitary Female Nurses Service. } \\
\text { Direction of the School of Nurses of the SSAP. } \\
\text { the duties of this female nurse were similar to those of } \\
\text { the directors and heads of services, meaning that in the } \\
\text { structure of the SSAP, the female nurse was in the same } \\
\text { hierarchical position as the other managers, who were } \\
\text { all men and doctors. }\end{array}$ \\
\hline $\begin{array}{l}\text { District } \\
\text { female } \\
\text { nurse }\end{array}$ & $\begin{array}{l}\text { - Work in the territory under the responsibility of the Health } \\
\text { Department where she was at. } \\
\text { - Manage the activities of the Health Department, as } \\
\text { determined by the chief female nurse. } \\
\text { - Guide and supervise the work of sanitary nurses working } \\
\text { at the Health Station, being responsible for the proper } \\
\text { execution of all activities required by the chief female } \\
\text { nurse and health authorities. } \\
\text { - Organize weekly and monthly reports of the work } \\
\text { performed. }\end{array}$ \\
\hline $\begin{array}{l}\text { Sanitary } \\
\text { nurse }\end{array}$ & $\begin{array}{l}\text { - Carry out technical work of the "art of a nurse", focusing } \\
\text { on maternal-child and school hygiene activities; } \\
\text { prophylaxis of tuberculosis, syphilis, and other sexually } \\
\text { transmitted diseases; and home isolation in cases of } \\
\text { compulsory reporting diseases. } \\
\text { - Show up at the Health Department at the times set by } \\
\text { the district female nurse. }\end{array}$ \\
\hline
\end{tabular}

Note:SSAP-Subsecretaria de Saúde e Assistência Pública (Sub Secretariat for Health and Public Assistance).

Source: Código Sanitário Estadual (State Health Code)(7); Mascarenhas (2018)(8).

In the State Health Code, it is identified that the EESSAP course was organized based on the EEDNSP curriculum, being conducted by SSAP technicians and divided into three moments ${ }^{(7)}$. This curriculum included knowledge from the health sciences, and specific knowledge on the area of modern nursing. It is observed that knowledge of the hospital administration area was also included, indicating that the female nurse's job also had the mission of managing health services, as provided for in the female nurses' duties set ${ }^{(8)}$.

Finally, in the period from the year 1925 to the year 1930, the female nurse's contribution to the implementation of health policy of the state of Bahia took place through the execution of sanitary education actions, home visits and hygienic surveillance ${ }^{(7,16-20)}$. During this period, the main objectives of the female nurse's work were to spread the hygienist precepts; supervise in loco the behaviors and living conditions and health of the population; apply corrective and punitive measures in case of non-compliance with the Health Code; serve as a link between the population and the expanding state health network; assist man/doctor work and stimulate compliance with medical and sanitary orders ${ }^{(8)}$.

\section{DISCUSSION}

In the context of the years 1920s, the Brazilian State invested in the qualification of doctors/sanitarians and inserted a new category of worker in the area of public health, the modern female nurse ${ }^{(21)}$, whose workforce was a tool to carry out the social control intended by the emerging health policy ${ }^{(8)}$.

In the public health of Bahia state, the woman/nurse's work was institutionalized and organized based on the social and technical division of labor ${ }^{(8)}$. This way of organizing nursing work met the current health policy model and reproduced within health institutions "the class structure of capitalist society, through professional hierarchy". This hierarchy"is made explicit in the very division of intellectual labor versus manual labor, which was the basis for the training of Nightingale nurses"(22), which was also identified in the Female Nurses Service of DNSP(4).

As occurred at the federal level, in the state of Bahia the social and technical division of labor conditioned the female nurse's place to the position occupied by this worker in the formal structure of the State health apparatus ${ }^{(8)}$. This way of organizing work was replaced from the North American public health model and fragmented nursing work into intellectual activities (head of services, supervision of the work process, preparation of auxiliary personnel) and manually performed activities (individual or collective actions performed in households and communities) ${ }^{(22)}$.

At SSAP, the social and technical division of health work impacted the relationships established between the woman/nurse and the man/doctor, as well as the salary paid to these workers ${ }^{(8)}$. The difference in received salaries by men and women highlights the sexual division of labor in public health and the reproduction in the public area of unequal relations between men and women ${ }^{(8)}$. According to Hirata and Kergoat ${ }^{(23)}$, the sexual division of labor is historically and socially moderated, being a "form of division of social labor resulting from social relations between the sexes; more than that, it is a priority factor for the survival of the social relationship between the sexes".

In this regard, the sexual division of labor enables "the appropriation by men of functions with greater social value"; "lower gender to biological sex"; "reduces social practices to sexual 'social roles' that refer to the natural destiny of the species" and has as organizing principles the separation between female and male work (there are jobs for men and those for women) and the hierarchy between female work and male work ("a man's work" is worth more than a woman's work") (23).

As a consequence of the sexual division of labor, the work of the woman/nurse was born with less economic value and hierarchically lower to the work of the man/doctor, despite being qualified and contributing to the viability of state health policy ${ }^{(8)}$. This allowed the State to use the female nurse's workforce to reproduce in the public sphere the "role of women" in the domestic environment, confirming the ideology that women's work is based on qualities, not on qualification ${ }^{(24)}$.

Still in the conception of the same authors ${ }^{(24)}$, the place occupied by the female nurse in the State health apparatus was conditioned by the gender relations established in that historical context, which were also predominant in determining the price attributed to the female nurse's workforce ${ }^{(24)}$. For this reason, it 
was assigned to the nurse the activities related to manual work, control, a permanent surveillance and the organization of health services, to complement the work of the man/doctor and ensure that his orders were obeyed to guarantee the result of therapy ${ }^{(8)}$.

Regarding the value of the female nurse's workforce, it is emphasized that the work of the woman/nurse, even though it is important for the economic production mode, does not add more price to the workforce because the female workforce is given less value, for being considered complementary labor and for performing functions called low complexity, manually performed and repetitive. Even when the qualification of female nurses has become more complex, this has little impact on the salaries paid to these workers, although, contradictorily, the increase in the qualification time is one of the factors considered to raise the value of the workforce ${ }^{(24)}$. This fact further demonstrates that social determinations of gender historically have greater weight in establishing the value of the female nurses' work in Brazilian society.

When it comes to the qualification of nurses within the scope of SSAP, this was carried out at EESSAP ${ }^{(8)}$. This School stipulated the same elitist, rigid and discriminatory criteria for the selection of female students from the EEDNSP(25), that directed "the selection to a universe of'noble' women, without physical impairments and with publicly attested morality"(4) and restricted access to the nursing profession to women who had a good educational background, a situation that in the years of 1920s was limited to women of high socioeconomic status ${ }^{(26)}$.

From the perspective of Pires ${ }^{(27)}$, these criteria were established to constitute a professional elite in the area of nursing and break with the retrograde conception about the female nurse's work that prevailed in the social imaginary of Brazilians, as Fraenkel points out ${ }^{(28)}$ : in the years of 1920s "(...) the people had a century late concept of nurses; like that of England before Florence Nightingale, that is, more or less in the year 1820, a time when this profession was still of a subservient type"(28). Alcântara ${ }^{(26)}$ reinforces this observation when stating that when comparing the Brazilian society of the years 1920s with the English and North American societies of the second half of the $19^{\text {th }}$ century, a time when modern nursing was institutionalized in these places, a common aspect is identified: the negative concept attributed to the female nurse's work and the nursing area ${ }^{(26)}$.

It is noteworthy that the professionalization of the female nurse's workforce did not face medical hegemony in the health sector and male hegemony in society. On the contrary, the ideological bases that structured the professional work of the Brazilian female nurse reinforced the subservience of the woman/nurse to men, doctors, and the State ${ }^{(27)}$. This was duly absorbed by the political leaders of nursing, who publicly emphasized "the role of the mother nurses, their charitable spirit and the role as home administrator, without questioning the reasons why this role was attributed to her or the reasons why the wage gap perceived by working men and women"(27). So,"the dominant values and ideology were absorbed as the values and ideology of nursing"(27). This ideological component defined the female nurse's place in public health (hierarchically lower to the doctor) and guided the training of nurses within the SSAP.

Beyond these aspects, it is listed that the contribution of female nurses in the construction of the health policy of the state of Bahia took place through the implementation of structuring actions of the health policy, such as sanitary education, home visits and hygienic surveillance, notably as of the year $1927^{(8)}$.

It is worth mentioning that home visits made by female nurses provided permanent surveillance of social life through the regulation and inspection of individual behaviors (regarding compliance with medical and sanitary standards and lifestyle habits prescribed by health authorities); the adoption of prophylactic measures, including when the disease was installed; the prevention of infectious diseases, such as tuberculosis and syphilis; and the spread of good manners in hygiene through sanitary education ${ }^{(8)}$. In these terms, it was up to female nurses to obtain the population's consensus for the adoption of hygienist habits and to domesticate people's bodies ${ }^{(5)}$, besides representing the concerns of the ruling class with the population.

Concerning the sanitary education provided by female nurses at home, it is considered that this action aimed to coach the population to prevent the occurrence and spread of diseases, seeking to restrain behaviors that would harm the community and convince people regarding hygiene habits (food, personal, sexual, home, mental, mother and child) considered correct by hygienists ${ }^{(8)}$. This way of conceiving educational practice, in addition to having a dictatorial and punitive approach, was based on the assumption that economically lower social classes ignored the rules of how to lead their own lives and could only adopt appropriate behaviors by incorporating hygiene habits in their daily lives ${ }^{(29)}$.

Besides instrumental aspects, sanitary education carried out at the household also succeeded to complement the work of doctors performed in health services. For this reason, the female nurse was considered an auxiliary worker and her work was submitted to the supervisory and hierarchically superior view of the man/doctor ${ }^{(8)}$. In the role of assisting the doctor, women/nurses "were essential in ensuring that medical recommendations were met, assisting the provision of medicines, promoting the coming of patients and pregnant women, mothers and children to outpatient services"(5).

The identification of the female nurse as an assistant to the doctor dates to the $19^{\text {th }}$ century, when medical work began to expand the scope of its practices and to use increasingly complex technologies to diagnose and treat diseases ${ }^{(30)}$. In the meantime, routine care activities (checking vital signs, controlling a person's general condition, placing catheters, dressings, sample collection for exams, among others) were gradually passed on to "paramedic" personnel (specifically, women/nurse), who should also prepare the material necessary for medical practice and carry out the measures prescribed by doctors ${ }^{(30)}$.

As an auxiliary of the man/doctor, the woman/nurse should never be ahead of the doctor and her work was ideologically conceived as a religious mission fulfilled with piety, devotion, obedience and renunciation (qualities presented as feminine), whose focus was "serving the sick, an object of the care purpose and, in their attention, serving doctors, serving the institution that treats them and their representatives" ${ }^{\prime \prime 30)}$. Besides that, as a physician's assistant, the nurse would have the dual role of being an information agent (concerning the health status, the evolution of the disease and the effectiveness of the prescribed therapy) and an execution agent of medical orders ${ }^{(30)}$.

Thus, the work of the woman/nurse "develops a practice of care entirely reliant on medical practice, an exercise of which eases considerably", since it makes the diagnosis of diseases and prognosis 
feasible, besides ensuring strict compliance with medical therapy ${ }^{(30)}$. This way, "this double belonging of nursing practice, simultaneously, the beneficiary of the religious model and submitted to the medical model, will deeply mark, in France, the way of identifying this practice", which remains from the end of the $19^{\text {th }}$ century to the years $1970 \mathrm{~s}^{(30)}$.

Such characteristics of the female nurse's work were also identified in the year 1930, allowing us to infer that between the years 1925 and 1930, the female nurse's work was institutionalized in the area of public health to assist the work of the man/doctor, to be the link between the State health apparatus, medical work and the population, besides being a strategic instrument for domesticating bodies and for social control, which was carried out through home visits, sanitary education and hygienic surveillance ${ }^{(8)}$.

\section{Study limitations}

As it is a theme little explored in the historiography of the nursing on the state of Bahia, the documentary sources used in the study were predominantly official. For future research, it is recommended to identify other types of documentary sources to guarantee the diversity of points of view and deepen the understanding of the analyzed phenomenon.

\section{Contributions to the Area}

This research exposes new horizons in the history of nursing in the state of Bahia and allows us to understand the relationship established between the state health policy and the female nurse's work. From a historic point of view, this study contributes to the advancement of knowledge about the history of nursing in the state of Bahia, given that it pioneered aspects of the training and work of nurses in the years of 1920s.
It should be noted that in the historiography on nursing of the state of Bahia, there are no studies whose object of study consider aspects of the education and work of female nurses in the state of Bahia in the years 1920s, except for a chapter in the study by Ramos ${ }^{(5)}$. Therefore, the evidence analyzed in the present study makes it possible to deepen the analysis of the historical development of nursing in the state of Bahia and Brazil.

\section{FINAL CONSIDERATIONS}

The female nurse's contribution to the construction of the health policy of the state of Bahia occurred through sanitary education actions, home visits and hygienic surveillance. These actions were structuring for the implementation of health policy between the years 1925 and 1930, since it allowed the complementation of the work of doctors, the domestication of bodies, the imposition of the precepts of private hygiene for the population, particularly women and children, and the social control intended by fractions of the Brazilian medical elite.

It is noteworthy that in the years of 1920s, the female workforce was considered one of the main routes for the spread of good manners in hygiene socially, placing itself as an ideal instrument to access homes and instruct/advise people in their daily lives to adopt behaviors that avoid the occurrence and, above all, the spread of diseases. Despite this, there were no records of female nurses' contributions to policymaking and decision-making processes.

Finally, the female nurse's contribution in the implementation of the health policy of the state of Bahia, from the years 1925 to 1930, enabled the public health policy instituted by the State, revealing the political concerns that made possible the constitution of a work area marked by the social and sexual division of work since its genesis in Brazil.

\section{REFERENCES}

1. Hochman G. A Era do Saneamento: as bases da política de Saúde Pública no Brasil. São Paulo: Hucitec; 2012. 249 p.

2. Braga JCS, Paula SG. Saúde e Previdência: estudos de política social. São Paulo: CEBES-HUCITEC, 2006. 224 p.

3. Castro Santos LA. As origens da Reforma Sanitária e da modernização conservadora na Bahia durante a Primeira República. Dados. 1998;41(3). doi: 10.1590/S0011-52581998000300004

4. Mascarenhas NB, Melo CMM, Silva L.A. Genesis of the professional work of nurses in Brazil (1920-1925). Esc Anna Nery. 2016;20(2):220-7. doi: $10.5935 / 1414-8145.20160029$

5. Ramos FM. A enfermeira na história da vigilância epidemiológica no estado da Bahia. [Monografia] [Internet]. Salvador: Escola de Enfermagem, Universidade Federal da Bahia; 2011 [cited 2020 Apr 21]. Available from: https://blog.ufba.br/grupogerirenfermagem/files/2017/05/FERNANDAMOTA-RAMOS-A-ENFERMEIRA-NA-HIST\%C3\%93RIA-DA-VIGILANCIA-EPIDEMIOLOGICA-NO-ESTADO-DA-BAHIA.pdf

6. Nery GC. A organização sanitária do estado da Bahia: algumas notas para o estudo de sua história. Rev Baiana Saúde Pública [Internet]. 1982 [cited 2020 Apr 21];9(1):45-51. Available from: http://rbsp.sesab.ba.gov.br/index.php/rbsp/article/view/891/467

7. Governo do Estado da Bahia. Decreto n 4.144, de 20 de novembro de 1925. Approva o Código Sanitário do Estado da Bahia. Diário Oficial do Estado da Bahia, Salvador, 22 nov. 1925.

8. Mascarenhas NB. Estado, política de saúde e trabalho da enfermeira na Bahia (1925-1951). [Tese]. Salvador: Escola de Enfermagem, Universidade Federal da Bahia, Salvador; 2018.

9. Correia MVC. O Conselho Nacional de Saúde e os Rumos da Política de Saúde Brasileira: mecanismo de controle social frente às condicionalidades dos organismos financeiros internacionais. [Tese] [Internet] Recife: Centro de Ciências Sociais Aplicadas, Universidade Federal de Pernambuco, 2005[cited 2020 Apr 21]. Available from: https://repositorio.ufpe.br/handle/123456789/9680

10. Paim JS. Saúde Política e Reforma Sanitária. Salvador: ISC-CEPS;2002. 447 p. 
11. Merhy EE. A Saúde Pública como Política: os movimentos sanitários, os modelos tecnoassistenciais e a formação das políticas governamentais. Porto Alegre: Rede UNIDA; 2014. 313 p.

12. Teixeira CF, Silveira P. Glossário de Análise Política em Saúde. Salvador: Edufba; 2016. 222 p.

13. Bauer MW, Aarts B. A construção do corpus: um princípio para coleta de dados qualitativos. In: Pesquisa qualitativa com texto, imagem e som: um manual prático. Petrópolis: Vozes; 2007. p. 39-63.

14. Barros Barreto ALCA. Relatório da Sub-Secretaria de Saúde e Assistência Pública. Bahia: Imprensa Official do Estado. 1926.

15. Governo do Estado da Bahia. Lei n 1.811, de 29 de junho de 1925. Organiza a Sub-Secretaria de Saúde e Assistência Pública. Diário Oficial do Estado da Bahia, Salvador, 02 ago., 1925.

16. Barros Barreto ALCA. Relatório da Secretaria de Saúde e Assistência Pública (anno de 1929). Bahia: Imprensa Official do Estado, 1930.

17. Governo do Estado da Bahia. Lei no 1.933, de 21 de julho de 1927. Cria a Secretaria de Saúde e Assistência Pública em substituição a Subsecretaria de Saúde e Assistência Pública. Diário Oficial do Estado da Bahia, ano XII, n.204, p.4947-4948, Poder legislativo, Bahia, 24 de julho de 1927.

18. Governo do Estado da Bahia. Secretaria de Saúde e Assistência Pública. Portaria n. 279. Diário Oficial do Estado da Bahia, p. 3208. Salvador, 30 jul. 1927.

19. Governo do Estado da Bahia. Secretaria de Saúde e Assistência Publica. Diretoria de Higiene Infantil e Escolar. Relatório dos trabalhos executados pela Directoria de Hygiene Infantil e Escolar no anno de 1928. Salvador, 1928.

20. Governo do Estado da Bahia. Secretaria de Saude e Assistencia Publica. Diretoria de Higiene Infantil e Escolar. Relatório da Directoria de Hygiene Infantil e Escolar apresentado pelo Dr. Joaquim Martagão Gesteira (anno de 1929). Salvador, 1929.

21. Castro Santos LA, Faria L. Saúde e história. São Paulo: Aderaldo \& Rothschild; 2010. 328 p.

22. Melo C. Divisão social do trabalho e Enfermagem. São Paulo: Cortez, 1986. 95 p.

23. Hirata H, Kergoat D. Novas configurações da divisão sexual do trabalho. Cad Pesqui. 2007;37(132):595-609. doi: 10.1590/ S0100-15742007000300005

24. Santos TA, Melo CMM, Leal JAL. The Value Nurse Workforce. Int J Nurs. 2016;3(1);29-7. doi: 10.15640/ijn.v3n1a4

25. Germano RM. Educação e Ideologia da Enfermagem no Brasil. São Caetano do Sul: Yendis; 2007. 160 p.

26. Alcântara G. A enfermagem moderna como categoria profissional: obstáculos à sua expansão na sociedade brasileira[Tese]. Ribeirão Preto: Escola de Enfermagem, Universidade de São Paulo, 1963.

27. Pires D. Hegemonia médica na saúde e a enfermagem. São Paulo: Cortez, 1989. 156 p.

28. Fraenkel E. Histórico do serviço de enfermeiras do Departamento Nacional de Saúde Publica. Annaes de Enfermagem. 1934;1(3):14-0.

29. Barreira IA. A enfermeira Ana Néri no país do futuro: a aventura da luta contra a tuberculose. [Tese]. Rio de Janeiro: Escola de Enfermagem Anna Nery, Universidade Federal do Rio de Janeiro, 1992.

30. Collière MF. Promover a vida: a prática das mulheres de virtude aos cuidados de enfermagem. Porto: LIDEL; 1999. 384 p. 